\title{
A membrane transporter for tryptophan composed of RNA
}

\author{
TERESA JANAS, TADEUSZ JANAS, and MICHAEL YARUS \\ Department of Molecular, Cellular, and Developmental Biology, University of Colorado, Boulder, Colorado 80309-0347, USA
}

\begin{abstract}
We have incorporated an RNA binding site for the biological amino acid tryptophan within an RNA complex with affinity for phospholipid bilayer membranes. The resulting RNA $\left(9: 10_{\text {Trp }}\right)$ creates a selective route through the bilayer for the amino acid. Binding and enhanced tryptophan permeability are nonlinear in RNA concentration, suggesting that RNA aggregation is required for both. Tryptophan permeability saturates with increased concentration, though at $\sim 1000$-fold greater level than when binding a free aptamer. The RNA $\left(9: 10_{\mathrm{Trp}}\right)$ complex, bound at a mean of two per liposome, halves the activation energy for tryptophan transport (to $46 \mathrm{~kJ} / \mathrm{mole}$ ), specifically increasing tryptophan entry to a maximal velocity of $0.5 \mathrm{sec}^{-1} \mathrm{per} \mathrm{liposome}^{-}$ with little or no accompanying increase in general permeability. Individual RNAs turn over tens of thousands of times at high tryptophan concentration. Thus, a specific passive membrane transporter whose properties overlap those of single-molecule transporter proteins, can be made of RNA alone. Permeability changes probably rely on disturbances in lipid conformation as well as on an advantageous low free energy position for tryptophan at the membrane. Other RNA activities may yield other RNA-membrane nanosystems via this route.
\end{abstract}

Keywords: carrier; selection; amino acid; nucleic acid; phospholipids; ribocyte

\section{INTRODUCTION}

RNA molecules readily bind phospholipid bilayers (Khvorova et al. 1999; Vlassov et al. 2001; Janas and Yarus 2003), probably residing within one of the two polar surface zones that comprise about half the membrane thickness (Wiener and White 1992). By selecting RNAs that chromatograph with liposomes, we have found many RNA complexes composed of $\sim 120$ nucleotide monomers which bind to dioleoylphosphatidylcholine bilayers (Vlassov et al. 2001). Such membrane RNAs oligomerize when free and, even more strikingly, within the membrane (Janas and Yarus 2003). RNAs we use here bind optimally as a 2:1 complex of RNA 9:RNA 10 with RNA contact via kissing loops (Vlassov et al. 2001). The crucial design principle is based on the observation that the two RNAs differ in function within the membrane complex. RNA 9 alone shows weak but detectable membrane affinity, suggesting that it incorporates the phospholipid site. In contrast, RNA 10 has no such activity, and may only be a linker (Janas and Yarus 2003) allowing the specific oligomerization of RNA 9.

Reprint requests to: Michael Yarus, Department of Molecular, Cellular, and Developmental Biology, University of Colorado, Boulder, Colorado 80309-0347, USA; e-mail: yarus@buffmail.colorado.edu; fax: (303) 492-7744

Article and publication are at http://www.rnajournal.org/cgi/doi/ 10.1261/rna.7112704.
These functional ideas are the basis for the transformation of the RNA (9:10) complex into a transporter. We combined two structures to form a bifunctional RNA $10_{\operatorname{Trp}}$ (Fig. 1) in which the hypothetically dispensable center of RNA 10 is substituted by a stereo-specific binding site for the amino acid tryptophan. The central (Fig. 1, yellow) nucleotides of RNA 10 were replaced by RNA 727-44 sequences (magenta). These latter sequences contain an internal bulge motif selected for tryptophan binding (I. Majerfeld and M. Yarus, in prep.). The Trp binding site is thereby flanked by loops containing sequences needed for complex formation and membrane affinity (Fig. 1, green). A base paired U-A inessential for amino acid affinity (Fig. 1, arrow) was changed to G-C to better favor the local structure of the tryptophan binding fold within the larger RNA.

The construction exploits the fact that these RNAs are expected to perturb regular lipid structures (Janas and Yarus 2003). Thus, they should bring bound tryptophan into apposition with a region of perturbed membrane lipid. Below we test the idea that this combination of actions will provide a specific route across the phospholipid bilayer for the RNA ligand tryptophan.

\section{RESULTS}

Testing amino acid binding and complex formation

To test the continued function of the Trp binding site within RNA $10_{\text {Trp }}$ (Fig. 1), we performed affinity chroma- 


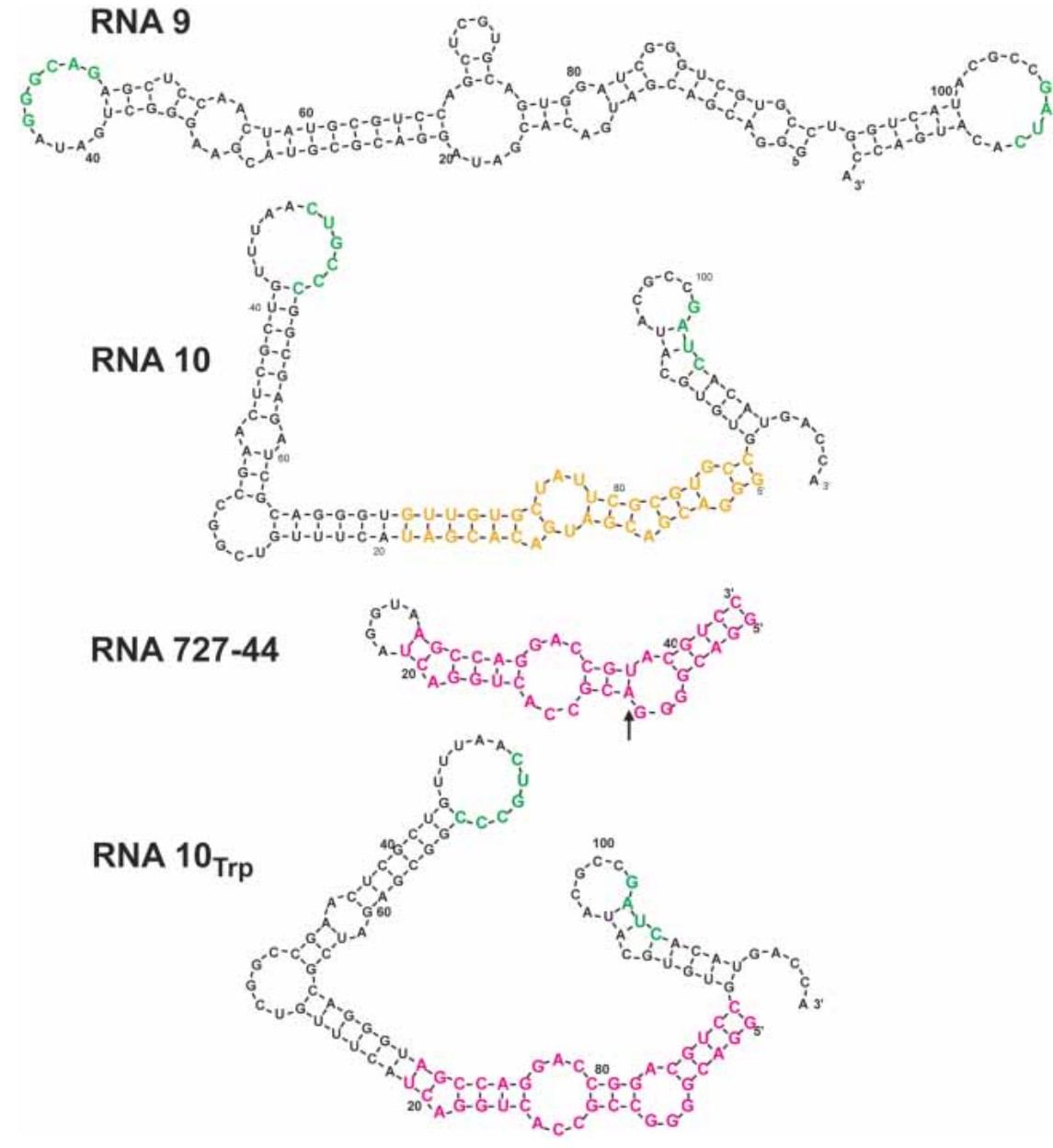

FIGURE 1. Proposed secondary structures for RNA 9, RNA 10, RNA $10_{\text {Trp }}$. Drawings are the output of BayesFold, a Bayesian RNA folding program (Knight et al. 2004; http://jaynes. colorado.edu/Bayes/). In RNA $10_{\operatorname{Trp}}$ a central region (yellow) has been replaced with a tryptophan binding site (RNA 727-44, magenta; I. Majerfeld and M. Yarus, in prep.). An arrow marks a sequence change (AU $\Rightarrow$ CG; nucleotides 9-82) introduced to increase the free-energy advantage of the correct fold for the tryptophan binding site. Flanking regions contain essential complementary loop sequences (Vlassov et al. 2001; green) for RNA (9:10) complex formation and membrane binding.

tography on Trp-Sepharose using both RNA $10_{\text {Trp }}$ (Fig. 2A) and the radiolabeled hybrid complex, RNA (9:10 $0_{\text {Trp }}$; Fig $2 \mathrm{~B})$. Both free and complexed RNA $10_{\operatorname{Trp}}$ is mostly folded into an active conformation, judged from the observation that two-thirds of both free and complexed RNA $10_{\operatorname{Trp}}$ bind to Trp-Sepharose and are eluted by a 1-mM Trp solution.

Radiolabeled RNA 9 alone, as expected, shows no affinity for the amino acid (Fig. 2C). On the other hand, radiolabeled RNA 9 in the presence of unlabeled RNA10 ${ }_{\text {Trp }}$ binds Trp-Sepharose and is affinity eluted by tryptophan (Fig 2D). Therefore, complex formation with RNA 9 has also survived construction of RNA $10_{\text {Trp }}$. This can be confirmed by native gel electrophoresis (Vlassov et al. 2001) showing stable complex formation between RNA 9 and RNA 10 $0_{\text {Trp }}$ with and without $1 \mathrm{mM}$ tryptophan (not shown). By integrating the total counts in RNA 9 and RNA 10 eluted by tryptophan in Figure 2, B and D, we calculate that the molar composition of RNA (9:10 $\left.{ }_{\text {Trp }}\right)$ is 1.2:1, somewhat less (Vlassov et al. 2001) than the 2:1 ratio in the parental RNA (9:10).

We wished to exploit the specificity of the tryptophan binding site in permeability experiments, so we tested free RNA (9:10 ${ }_{\text {Trp }}$ ) by elution from TrpSepharose with $1 \mathrm{mM}$ of nine different amino acids (Fig. 2E). Five prior, consistent isocratic affinity elution experiments (Ciesiolka et al. 1996) using 20 to $50 \mu \mathrm{M}$ L-Trp suggest that the $\mathrm{K}_{\mathrm{D}}$ of RNA (9:10 Trp) for L-Trp in solution is $7 \pm 1 \mu \mathrm{M}$ ( \pm SEM; data not shown), close to the dissociation constant of the original Trp site in RNA 727-44 (I. Majerfeld and M. Yarus, in prep.). Therefore, in Figure 2E, the RNA slowly elutes, even in the absence of ligand for the Trp site, as expected from its finite affinity for Trp-Sepharose. Nevertheless, several amino acids can be serially tested to see if they increase elution over the spontaneously dissociating tail. Millimolar L-Lys, Arg, His, Gln, Glu, Leu, Ile, and Phe are negligible eluants (Fig. 2E). Conversely, L-Trp works as expected, eluting remaining RNA counts per minute quantitatively. Recovery of RNA approximates $100 \%$ and a subsequent gentle column sweep without divalents (using $1 \mathrm{M} \mathrm{NaCl}$ ) elutes no RNA (Fig. 2E).

Thus, RNA (9:10 $\left.{ }_{\text {Trp }}\right)$ in solution is very specific for tryptophan and does not respond to other basic, acidic, polar, aliphatic, and aromatic amino acids. Taking these data conservatively as an indication that $\mathrm{K}_{\mathrm{D}}>1 \mathrm{mM}$ for the other amino acids (Ciesiolka et al. 1996), discrimination in favor of Trp is 150 -fold or greater.

\section{Binding to phospholipid bilayers tested}

Above we show that tryptophan affinity and RNA complex formation are intact. To now show that RNA (9:10 $\left.{ }_{\text {Trp }}\right)$ binds phosphatidylcholine membranes, we first used gel filtration on a column that voids liposomes but includes RNAs of this size (Khvorova et al. 1999). Figure 3A shows that free RNA $10_{\text {Trp }}$ is retarded by Sephacryl S-1000 as expected. Furthermore, RNA $10_{\operatorname{Trp}}$ is not displaced toward the void when exposed to phospholipid liposomes (Fig. 3A). Therefore, RNA $10_{\text {Trp }}$ shows no detectable membrane interaction. However, the inclusion of RNA 9 displaces la- 
A

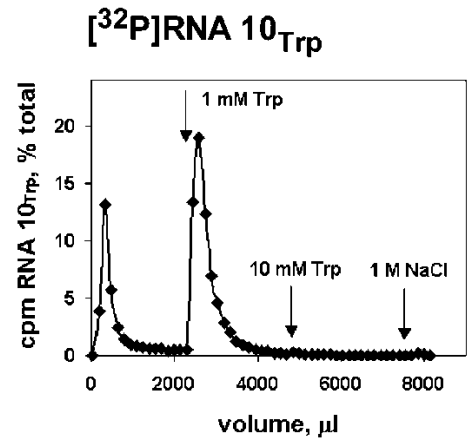

B

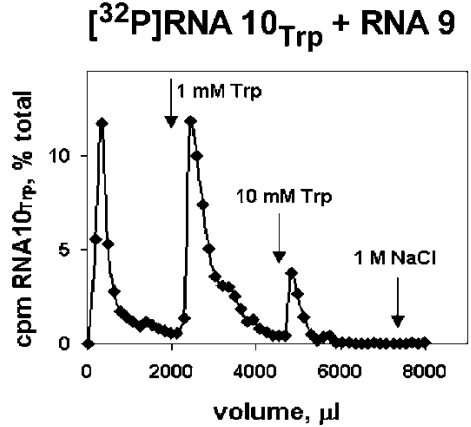

C $\left[{ }^{32}\right.$ P]RNA 9
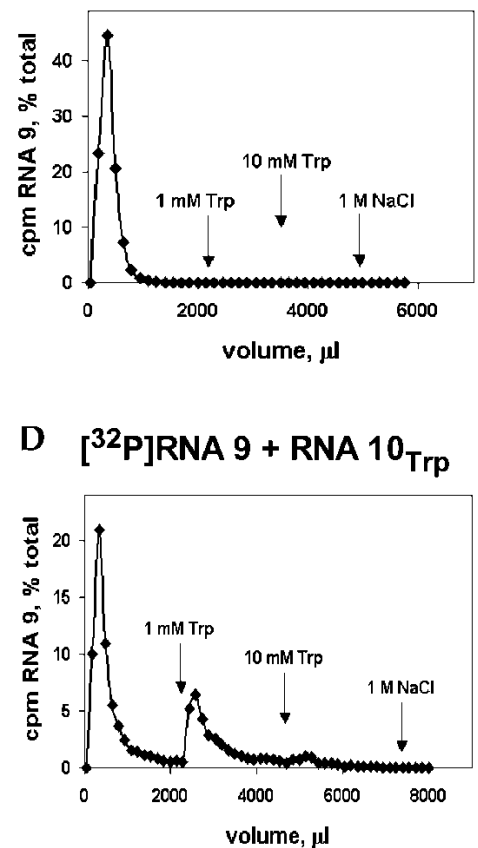

E

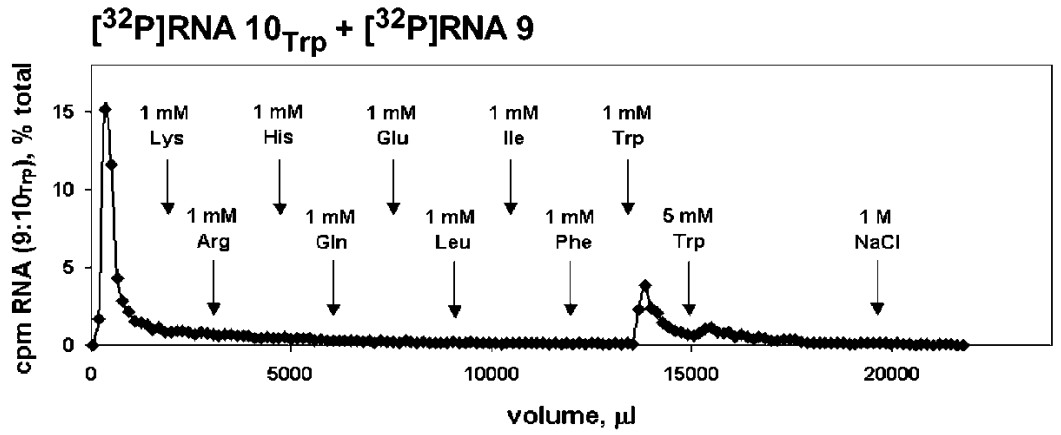

FIGURE 2. RNA affinity for L-tryptophan: Affinity elution from tryptophan-Sepharose using (A) $\left[{ }^{32} \mathrm{P}\right]$ RNA $10_{\text {Trp }},(B)$ RNA $\left(9:\left[{ }^{32} \mathrm{P}\right]\right.$ RNA $\left.10_{\text {Trp }}\right),(C)\left[{ }^{32} \mathrm{P}\right]$ RNA 9, $(D)\left(\left[{ }^{32} \mathrm{P}\right]\right.$ RNA 9:RNA $\left.10_{\operatorname{Trp}}\right),(E)$ amino acid selectivity assay by successive elution of affinity-immobilized RNA.

beled RNA $10_{\text {Trp }}$ into the void, tracking the liposome peak (Fig. 3B). Thus, though neither RNA alone binds well, RNA (9:10 $\left.{ }_{\text {Trp }}\right)$ efficiently binds phosphatidylcholine liposomes.

To confirm this essential quality of RNA (9:10 $\mathrm{Trp})$, we did FRET measurements between RNA labeled by the intercalated green dye, YOYO-1, and membranes labeled with the intercalated red dye, Texas Red (Janas and Yarus 2003). FRET is highly distance-dependent and becomes efficient only when the RNA enters the membrane, bringing the two bound fluors together. The data (Fig. 3C, fitted line) suggest a normal binding isotherm as the number of liposomes is increased, corresponding to $\mathrm{K}_{\mathrm{D}}=6 \pm 1 \mathrm{nM}$, considering one of our $100 \mathrm{~nm}$ diameter liposomes as a "site." Thus RNA (9:10 Trp $)$ binds phospholipid membranes by both qualitative and quantitative indices. To summarize the activities of RNA (9:10 $\left.{ }_{\text {Trp }}\right)$, the two RNAs are complexed, the tryptophan site is active, and affinity for phospholipid membranes is demonstrable.

\section{Permeability: Response to tryptophan and RNA concentration}

Figure 4 shows the result of varying external tryptophan concentration from $0.18 \mu \mathrm{M}$ up to the closest approach we can make to the solubility limit, $30 \mathrm{mM}$ L-tryptophan. At low concentrations the increase in uptake velocity due to RNA (liposome data subtracted) is accurately linear (low concentration points are not resolved in a linear plot like Figure 4). Saturation is observable, as expected for a limited number of amino acid binding sites, at an RNA-dependent velocity $\cong 0.5$ molecule sec $^{-1}$ liposome $\mathrm{e}^{-1}$ at $4^{\circ} \mathrm{C}$. However, half-saturation occurs at unexpectedly high L-tryptophan, about 5 $\mathrm{mM}$. This approaches 1000 -fold more concentrated tryptophan than required to saturate the free RNA $10_{\operatorname{Trp}}$ (above) so we suspect the action of the RNA binding site is altered on the phospholipid membrane.

The insets in Figure 4 show data for variation of the RNA concentration versus liposome binding (inset a), as well as RNA concentration versus RNA-dependent tryptophan permeation (inset b). We consider these independent experiments identical within experimental error. Roughly speaking, at low RNA concentration there is an upward-curving trend in both binding and permeability, then a point of maximal effectiveness at $\sim 0.6 \mu \mathrm{M}$ RNA. The data at lower RNA concentrations suggest that RNA molecules collaborate by complex formation to bind membranes and alter permeability. Such complex formation was documented previously using gel electrophoresis atomic force microscopy (Vlassov et al. 2001; Janas and Yarus 2003). Above $0.6 \mu \mathrm{M}$, it is possible that RNA aggregates become too large for optimal function. Below we have usually used the RNA concentration giving peak activity, $0.6 \mu \mathrm{M}$.

\section{Kinetics of the permeability effect}

We measured entry of external $0.18 \mu \mathrm{M}\left[{ }^{3} \mathrm{H}\right] \operatorname{Trp}$ into liposomes, using gel filtration in the presence of external nonisotopic tryptophan to remove external $\left[{ }^{3} \mathrm{H}\right]$ tryptophan (see Materials and Methods). Trp has a very hydrophobic 

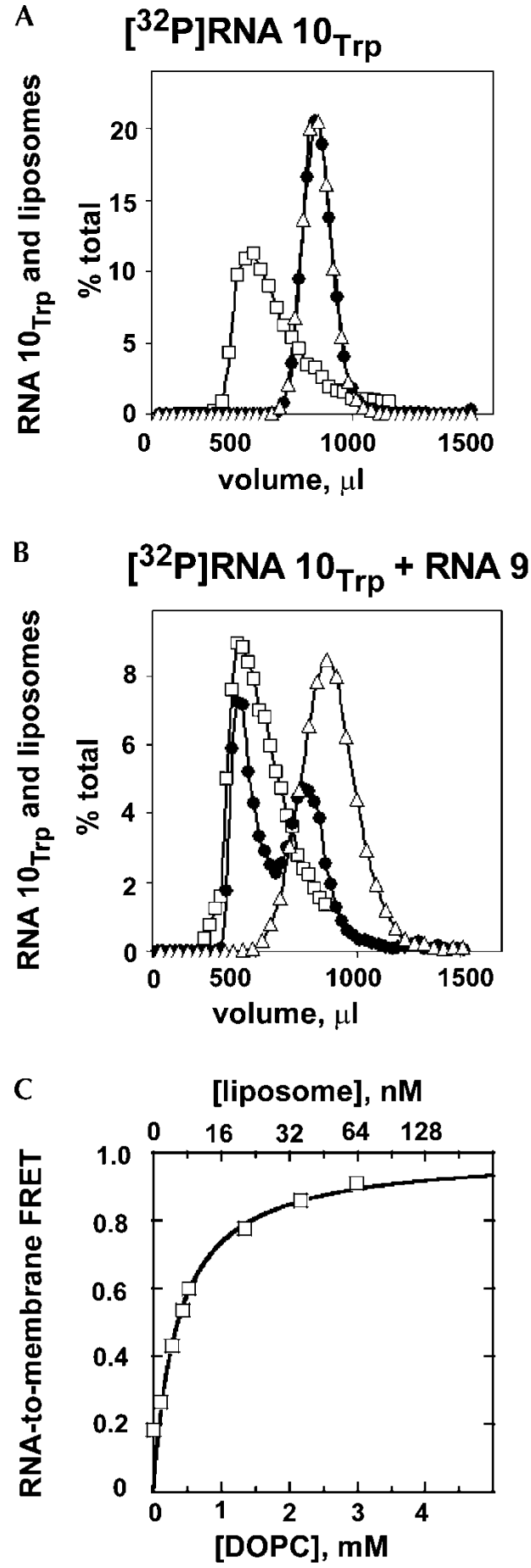

FIGURE 3. RNA affinity for phosphatidylcholine liposomes measured by gel filtration on Sephacryl S-1000. (A) $\left[{ }^{32} \mathrm{P}\right] \mathrm{RNA} 10_{\mathrm{Trp}}$ unreacted (triangles) and reacted (circles) with liposomes (as $\mathrm{OD}_{320}$, squares). (B) (RNA 9:[ $\left.{ }^{32} \mathrm{P}\right] \mathrm{RNA} 10_{\mathrm{Trp}}$ ) complex unreacted (triangles) and reacted (circles) with liposomes. Membrane affinity by RNA-tomembrane FRET: $(C)$ Membrane containing Texas Red titrated with YOYO-labeled RNA (9:10 Trp $)$ complex.

amino acid side chain, and so it has an easily detectable spontaneous entry rate. Our measured rates for this spontaneous permeation agree closely with previous literature determinations, thus supporting our permeability measurements (Chakrabarti 1994). As expected, final levels were always the same inside \pm RNA (Fig. $5 \mathrm{~A}$ inset), so only rate constants vary between experiments. Because RNA increased the inward rate without change in final steady-state Trp level, the implication is that RNA increased outward rate by the same factor, as required by the principle of Microscopic Reversibility.

Total tritium, as well as the much smaller amount of tritium within liposomes, co-chromatographed entirely with a sharp peak of non-isotopic L-tryptophan absorbance on HPLC (not shown). Therefore these ${ }^{3} \mathrm{H}$ measurements characterize membrane transit by bona fide tryptophan, not a radioactive contaminant or decay product.

Liposomes in the absence of RNA fill with Trp at a rate of $3.14 \pm 0.03 \times 10^{-3} \mathrm{~min}^{-1}$ at $4^{\circ} \mathrm{C}( \pm \mathrm{SEM}$; details available from yarus@colorado.edu). When RNA ( $\left.9: 10_{\operatorname{Trp}}\right)$ is present, this rate increases to $4.44 \pm 0.04 \times 10^{-3} \mathrm{~min}^{-1}$; the rate is $41 \% \pm 2 \%$ faster with RNA. To see what this overall change implies for the small number of bound RNAs, we must take a molecular viewpoint (below). However, a t-test shows that (Fig. 5B; details available from yarus@colorado.edu) the probability of this difference or greater, if normal populations have equal means, is only $1.8 \times 10^{-12}$. Thus Trp entry is certainly stimulated by RNA $\left(9: 10_{\operatorname{Trp}}\right)$. Similarly with no Trp binding site, the rate of Trp entry in the presence of RNA (9:10) is measured to be $3.32 \times 10^{-3} \mathrm{~min}^{-1}$. This rate difference is also overwhelmingly significant; the probability that RNA (9:10) liposomes and RNA (9:10 ${ }_{\text {Trp }}$ ) liposomes are the same is $3.4 \times 10^{-8}$. Therefore, RNA not only stimulates Trp entry, but stimulation is unmistakably dependent on the Trp binding site.

Furthermore, no significant Trp permeability effect oc-

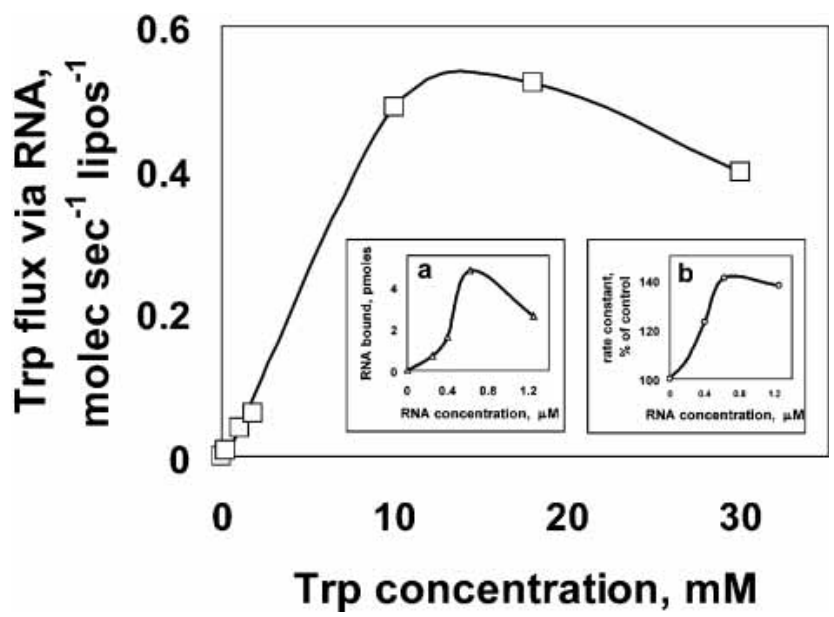

FIGURE 4. Membrane activities of RNA (9:10 Trp $)$ complex versus tryptophan concentration and versus RNA concentration. (Main panel) Concentration dependence of zero-trans Trp uptake due to liposome-bound RNA. (Inset a) Liposome-bound RNA versus RNA concentration. (Inset $b$ ) Relative tryptophan uptake rate as a function of RNA concentration. 
A

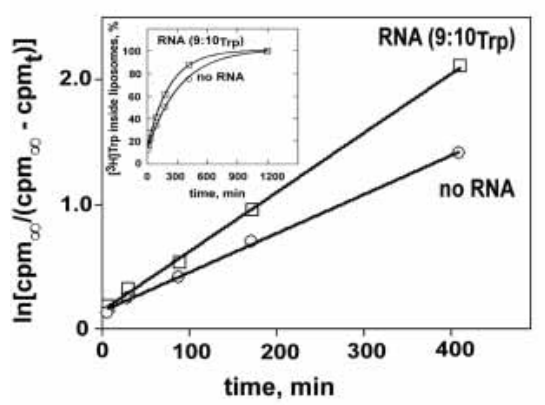

B

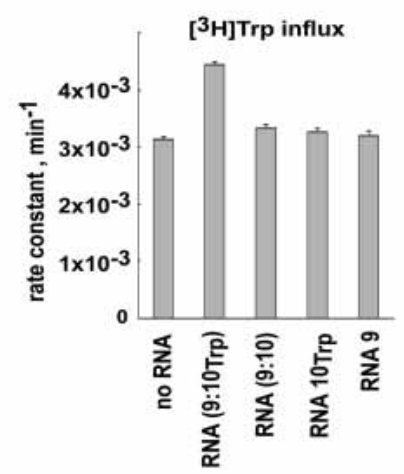

C

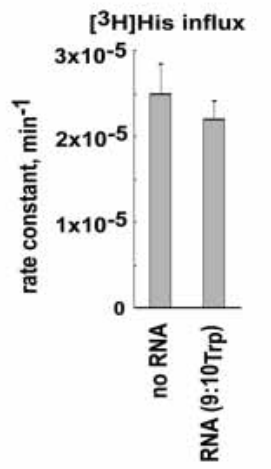

D

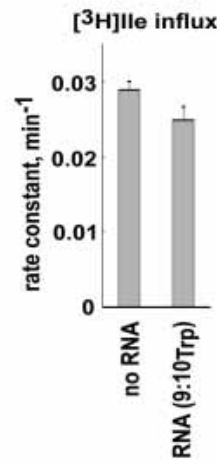

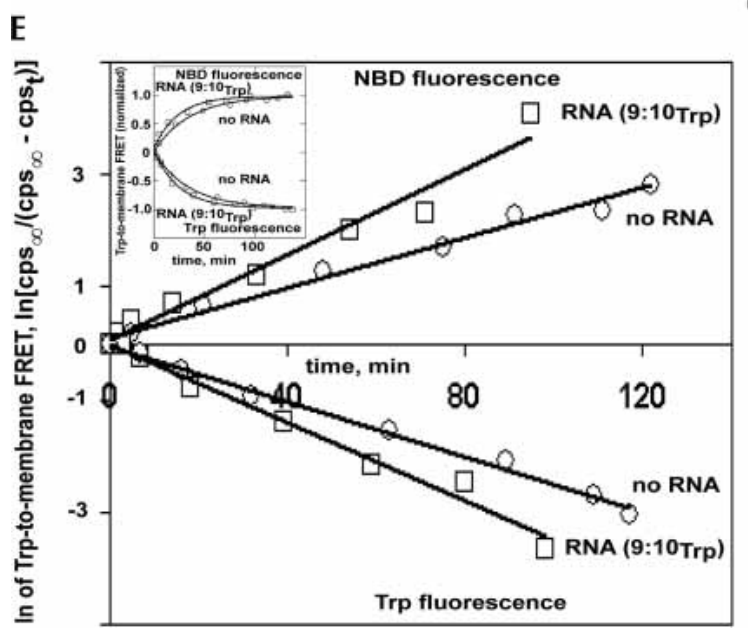

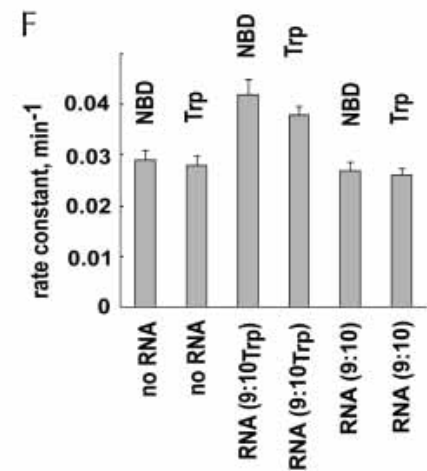

FIGURE 5. Kinetics of amino acid influx into phosphatidylcholine liposomes. Using scintillation counting of liposomes: $(A)$ representative $\left[{ }^{3} \mathrm{H}\right] \operatorname{Trp}$ experiment at $4^{\circ} \mathrm{C}$ showing convergence (inset) and slope proportional to rate, $\mathrm{k} ; \mathrm{cpm}_{\mathrm{t}}=\operatorname{cpm}_{\infty}\left(1-\mathrm{e}^{-\mathrm{kt}}\right) ;(B)$ average of seven rate constants with SEM bars for tryptophan; $(C)$ average of five rate constants with SEM bars for histidine; $(D)$ average of three rate constants with SEM bars for isoleucine. Using optical techniques: $(E)$ liposomal entry of tryptophan measured by $\operatorname{Trp} \rightarrow$ NBD-PE FRET at $4^{\circ} \mathrm{C}$ showing convergence (inset) and slope proportional to rate. $(F)$ Average of three FRET Trp uptake experiments with SEM bars.

curs for RNA $10_{\text {Trp }}$ alone and RNA 9 alone (Fig. 5B). Thus enhanced permeability is not evoked by an arbitrary RNA, but instead requires both RNAs of the complex and also the Trp site of the RNA (9:10 Trp) complex. The RNA complex appears to have little or no effect on general Trp permeability (probability of the no RNA versus RNA (9:10) difference $=0.016$ ). The absence of a significant general permeability effect is discussed further below.

\section{Specificity of the permeability effect}

The effect of the RNA (9:10 $\left.{ }_{\text {Trp }}\right)$ complex was specific for tryptophan; no significant increase of the influx rate was observed for $\left[{ }^{3} \mathrm{H}\right]$ histidine or $\left[{ }^{3} \mathrm{H}\right]$ isoleucine (Fig. $5 \mathrm{C}, \mathrm{D}$ ). Observations (available by e-mail from yarus@colorado. edu) actually show a non-significant decrease of permeability: $87 \pm 15 \%( \pm$ SEM) for both histidine in the presence of RNA (9:10 $\left.10_{\text {Trp }}\right)$ and $87 \pm 7 \%$ for isoleucine. This correlates with the observation (Fig. 2E, above) that these amino acids are not bound by the Trp site. Thus, RNA (9:10 $\left.0_{\text {Trp }}\right)$ does not generally increase membrane permeability to amino acids (as would an open aqueous conduit) but instead must use a more selective mechanism.

The presence of $0.2 \mathrm{mM}$ nonisotopic Trp inside liposomes has no effect on the rate of external $\left[{ }^{3} \mathrm{H}\right] \mathrm{Trp}$ entry in the presence of $0.6 \mu \mathrm{M}$ RNA; the ratio of Trp entry rates \pm internal Trp was $1.000 \pm 0.067( \pm$ SEM; a counterflow experiment). Thus, the membrane-active RNA does not perceive internal ligand, even at 1000 -fold the concentration of external Trp. Finally, external tritiated His does not enter more readily when external $0.2 \mathrm{mM}$ Trp is also present. Thus, Trp does not open a route for other amino acids; instead, it is uniquely transported. These observations together are as expected for simple, one-site facilitated diffusion via RNA ( $\left.9: 10_{\operatorname{Trp}}\right)$, in which transported amino acids must pass, one by one, through the unique external Trp binding site.

Because RNA transporter activity is unprecedented, we confirmed it using an independent technique, tryptophanto-membrane FRET (Fluorescence Resonance Energy Transfer) spectroscopy (Cajal et al. 1997). The intrinsic fluorescence of tryptophan was used as the origin of FRET. 
To make FRET dependent on importation of the amino acid into a vesicle, we measured tryptophan FRET to a fluor (NBD-PE; Cajal et al. 1997) incorporated specifically into the inner leaflet of a phospholipid liposome (McIntire and Sleight 1991). With internal NBD-PE only (external dye has been destroyed; see Materials and Methods), FRET from tryptophan to NBD requires crossing the membrane (Fig. 5E,F; data available by e-mail from yarus@colorado.edu).

RNA (9:10) without a Trp binding site did not increase membrane permeability to tryptophan $(93 \pm 8 \%$ of a control without RNA using Trp emission and $92 \pm 8 \%$ using NBD-PE emission). Therefore, the insignificant effect of RNA on general permeability is once again supported. However, tryptophan permeability with RNA $\left(9: 10_{\operatorname{Trp}}\right)$ was increased $144 \pm 14 \%$, using the rise in NBD-PE fluorescence, and increased $134 \pm 10 \%,( \pm$ SEM) using the decrease in Trp emission. Thus FRET confirms the dependence on the amino acid binding site and quantitatively confirms permeability enhancements measured using $\left[{ }^{3} \mathrm{H}\right] \operatorname{Trp}$. Because FRET is an optical method entirely independent of the above isotopic permeability measurements (for example, no purification of liposomes occurs), these congruent results strongly support RNA-mediated increases in membrane permeability to tryptophan of the magnitude cited.

\section{Activation energy}

In order to estimate the activation energy for tryptophan influx, experiments were performed at $4^{\circ} \mathrm{C}, 14^{\circ} \mathrm{C}$ and $24^{\circ} \mathrm{C}$ (description available by e-mail from yarus@colorado.edu). This $\left[{ }^{3} \mathrm{H}\right]$ tryptophan assay showed that the activation energy for tryptophan influx into unmodified phosphatidylcholine liposomes was $91 \pm 5 \mathrm{~kJ} /$ mole, whereas the value for influx via RNA (9:10 $\left.{ }_{\text {Trp }}\right)$ was $46 \pm 3 \mathrm{~kJ} /$ mole. RNA (9:10 $\left.{ }_{\text {Trp }}\right)$ therefore halves the activation energy for membrane passage by Trp. This reduction is greater than the binding free energy of the parental tryptophan site $(29 \mathrm{~kJ} / \mathrm{mole}$; calculated from $\mathrm{K}_{\mathrm{D}}$ ), so it may require contributions from both ligand binding and RNA-induced lipid rearrangement, as posited above.

\section{No role for liposome fusion}

We wished to be sure that the permeability effect of RNA (9:10 $\left.{ }_{\text {Trp }}\right)$ did not depend on liposome fusion. This is improbable even at the start, because it would require a special explanation for the observed amino acid selectivity, as well as for the measured differences between RNA (9:10) and RNA (9:10 Trp). However, we determined membrane fusion directly by encapsulating a fluor, aminonaphthalene trisulfonic acid (ANTS), in one set of dioleoylphosphatidylcholine liposomes and an effective fluorescence quencher, pxylene-bis-pyridinium (DPX), in another set (Ellens et al. 1985). Mixed liposomes detect vesicle fusion by quenching of ANTS fluorescence at $514 \mathrm{~nm}$. The lower solid line in Figure 6 shows the level of fluorescence expected for complete mixing of the fluor and quencher (ca. complete fusion); thus, mixing of liposome contents would be measurable. In fact, since a fusion hypothesis would require the involvement of most liposomes to explain permeation of the total liposome volume at an enhanced rate (Fig. 5A), the absence of any observable RNA (9:10 Trp) effect in this experiment (Fig. 6) effectively rules out liposomal fusion as an essential and pervasive step in Trp permeation.

\section{The magnitude of the increase in permeability per RNA}

We now narrow our focus to discuss transport at individual membrane RNA sites. At the optimal RNA concentration usually used, 12 RNA molecules were added per liposome. Measured binding (Fig. 3B) is $40 \%$, so 4.8 RNA per liposome are stably bound, on average. If the stoichiometry of these complexes is 1 molecule of RNA $10_{\text {Trp }}$ per 1.2 molecules of RNA 9, then there are about two Trp binding sites per liposome on average. Given the virtually complete dependence of increased permeability on the Trp binding site, most RNA-provoked phenomena likely occur at or very near the two Trp binding centers.

To gain an approximate microscopic view of Trp transport, we first assume that all RNAs are equally active. If they differ or only some are active, then we will calculate a minimum RNA effect. Conservatively, the cross sectional area of the RNA $10_{\operatorname{Trp}}$ is $16 \mathrm{~nm}^{2}$. This estimate maximizes the membrane surface required by considering RNA10 ${ }_{\text {Trp }}$ an A-form helix. A more realistic globular shape would be smaller in cross section, and give a higher apparent activity. A $200-\mathrm{nm}$ diameter liposome has a surface of $1.26 \times 10^{5}$ $\mathrm{nm}^{2}$. Two RNA $10_{\text {Trp }}$ therefore occupy $0.025 \%$ or $1 / 4000$ of the surface, where the increased permeability takes place.

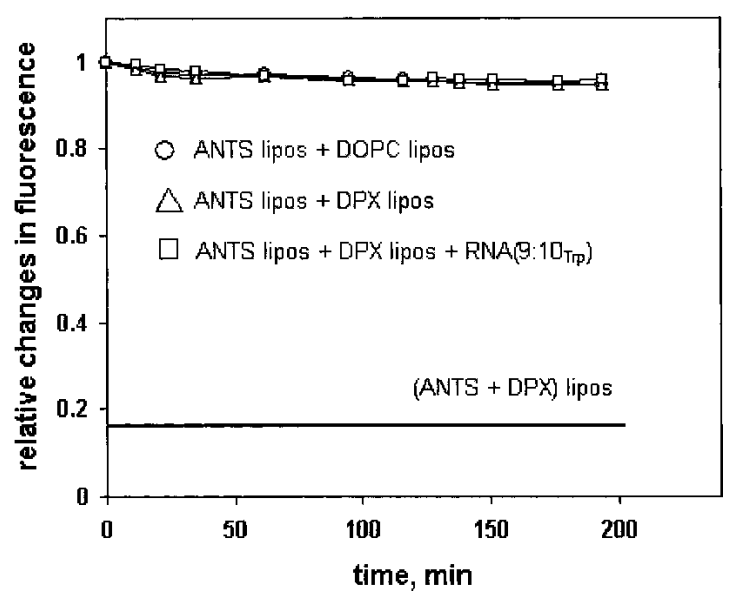

FIGURE 6. Fluorometric liposomal fusion assay measuring the interaction of liposomes containing a fluor (ANTS) with others containing a quenching agent (DPX). 
Using our most precise data, a $41 \%$ increase in tryptophan influx implies a permeability increase due to RNA of greater than $0.41 \times 4000 \approx 1640$-fold, or about 820 -fold for each RNA $10_{\text {Trp }}$ /tryptophan binding site.

\section{Turnover}

Tryptophan uptake increases with tryptophan concentration outside. Unmodified liposomes show an approximately linear increase in total tryptophan uptake as the concentration of Trp increases. After subtraction of this background uptake, the maximal RNA-induced uptake per liposome was $\sim 0.5 \mathrm{sec}^{-1}$ (Fig. 4), so the true first order rate is $\cong 0.25$ $\sec ^{-1}$ at $4^{\circ} \mathrm{C}$ for each RNA10 ${ }_{\text {Trp }}$. At high, saturating Trp concentrations, in the $1700 \mathrm{~min}$ of the usual kinetic experiment, each transporter site turns over in the inward direction more than 25,000 times. Thus the RNA transporter performs many identical permeation cycles, as also do proteins. Multiple turnover occurs at a constant rate (Fig. 5); this suggests that the RNA porter has a stable, consistent membrane conformation.

Finally, in order to pass tryptophan only, a Trp carrier is apparently logically required to have two functional orientations, one in which it acquires Trp from bulk solution and the other for release of bound Trp toward the membrane. Transport may therefore be mediated by repetitive molecular motions at $0.25 \mathrm{sec}^{-1}$ involving the Trp binding site of RNA (9:10 $\operatorname{Trp})$.

\section{Known RNA properties can explain increases in specific permeability}

A mechanism for facilitated tryptophan permeation is evident from prior data. We found that membrane RNAs prefer the edges of the lipid bilayer and other sites where irregular lipid conformations occur (Janas and Yarus 2003). This suggests that membrane RNAs prefer and stabilize irregular lipid conformations, perhaps including those required to form transmembrane defects. There is experimental evidence of the existence of transient, aqueous defects in membranes (Smith et al. 1984; Paula et al. 1996; Sandre et al. 1999), as well as evidence that polar molecules must traverse such routes crossing the bilayer (Paula et al. 1996). The observed 800 -fold increase in permeability would require $\approx 2,000$-fold increase in defect lifetime (Raphael 2001). This seems plausible because it requires only about $20 \mathrm{~kJ} /$ mole stabilization of the defect, corresponding to a few secondary interactions. The defect density of a phosphatidylcholine bilayer is otherwise very small-defects occupy only $2 \times 10^{-7}$ of an unperturbed membrane (Smith et al. 1984). Thus, we suggest that RNA $\left(9: 10_{\operatorname{Trp}}\right)$ is the stabilizing nucleus of an aqueous, membrane-crossing defect.

However, the stabilized defect must be mostly blocked by RNA $\left(9: 10_{\operatorname{Trp}}\right)$ to explain its relative inaccessibility to free tryptophan, isoleucine, and histidine. Only RNA-bound tryptophan has access, and thereby, increased permeability. This difference between previous observations (Khvorova et al. 1999; Vlassov et al. 2001) of increased general permeability and these present results may be explained by the use of 10- to 15-fold fewer RNA molecules per liposome here, or by unanticipated molecular changes accompanying the introduction of the Trp site.

\section{Comparison to proteins}

Turnover numbers of protein transporters (Stein 1990) are usually in the range of 0.1 to $1000 \mathrm{sec}^{-1}$. Protein transporters that use specific binding sites to move one molecule per cycle have rates at the slower end of this range. A mitochondrial ADP/ATP carrier works at $0.05-0.1 \mathrm{sec}^{-1}$ at $25^{\circ} \mathrm{C}$ (Schonfeld et al. 1996), while the glucose transporter in human erythrocytes turns over at $600 \mathrm{sec}^{-1}$ at $20^{\circ} \mathrm{C}$ (Stein 1990). The activation energy for protein transmembrane porters is usually in the range 40 to $130 \mathrm{~kJ} / \mathrm{mole}$, for example, sulfate ion transport by band 3 protein in human erythrocytes is at $\mathrm{E}_{\mathrm{A}}=131 \mathrm{~kJ} / \mathrm{mole}$ (Janas et al. 1988) and, for the Glossina morsitans proline transporter, $\mathrm{E}_{\mathrm{A}}=46 \mathrm{~kJ} /$ mole (Njagi et al. 1992). In this context, RNA $\left(9: 10_{\operatorname{Trp}}\right)$ at $\geq 0.25 \mathrm{sec}^{-1}$ and $46 \mathrm{~kJ} / \mathrm{mole}$ is both quantitatively and, by mechanism, comparable to slower protein transporters, and therefore appropriately called a tryptophan transporter made of RNA.

\section{Potential role in cellular life}

These findings suggest that RNA may have been underestimated as an active agent in biological processes. In particular, RNA-mediated transport might have been essential to early cellular life. Amphipathic lipids should have been freely available on the early Earth (Deamer et al. 2002) and growth of membrane-bound compartments via lipid assimilation is facilitated by common clay minerals (Hancyzc et al. 2003). However, a lipid bilayer enclosing an RNA cell (ribocyte) must exhibit specific molecular permeabilities in order to retain intermediates and import substrates. For a ribocyte living before the advent of templated peptide synthesis (Yarus 2002), specific permeability modification probably requires membrane RNAs. By whatever means RNA accomplishes the reaction, it is clear from this work that specific membrane transport is within the RNA repertoire. Following Bayes' Theorem, such confirmed predictions necessarily make an RNA world and its ribocytes more probable (Yarus 2002).

\section{Extension of the method to other RNA activities}

Finally, these data taken together corroborate the initial assumptions used to design RNA $\left(9: 10_{\operatorname{Trp}}\right)$. As we originally supposed, RNA 10 can be substituted with an indepen- 
dently derived RNA motif, $\mathrm{x}$, without disrupting the ability of the RNA $\left(9: 10_{\mathrm{x}}\right)$ complex to bind phospholipid bilayers or disrupting the activity of the substituted motif. This suggests that other nanoconstructions would be successful. For example, using protein aptamers, any protein could be made a peripheral membrane protein, or using ribozymes, any catalytic acceleration in the RNA repertoire could be conferred on membranes.

\section{MATERIALS AND METHODS}

\section{Affinity chromatography}

A total of 10 pmole RNA (6.7 pmole RNA 9, 3.3 pmole RNA10 ${ }_{\operatorname{Trp}}$ ) in water was heated for $3 \mathrm{~min}$ at $65^{\circ} \mathrm{C}$, brought to $1 \times$ buffer ( 50 $\mathrm{mM}$ Hepes at $\mathrm{pH}$ 7.0, $250 \mathrm{mM} \mathrm{NaCl}, 5 \mathrm{mM} \mathrm{MgCl}_{2}, 2 \mathrm{mM} \mathrm{CaCl}_{2}$ ), allowed $10 \mathrm{~min}$ at room temperature, loaded onto the $0.2-\mathrm{mL}$ column at $23^{\circ} \mathrm{C}$, and eluted with $1 \times$ buffer. Trp-Sepharose contained about $1.2 \mathrm{mM}$ L-tryptophan. Fractions contained about $150 \mu \mathrm{L}$.

\section{Gel filtration}

A total of 25 pmole RNA (in Fig. 3; molar ratio 2 RNA 9:1 RNA 10) in water was held for $3 \mathrm{~min}$ at $65^{\circ} \mathrm{C}$, brought to $1 \times$ buffer $\mathrm{H}$ (50 mM Hepes at $\mathrm{pH} 7.0,50 \mathrm{mM} \mathrm{NaCl}, 5 \mathrm{mM} \mathrm{MgCl}, 2 \mathrm{mM}$ $\mathrm{CaCl}_{2}$ ) and cooled to room temperature over $10 \mathrm{~min}$. DOPC liposomes $(10 \mathrm{mg} / \mathrm{ml})$ were incubated with RNA $(0.6 \mu \mathrm{M})$ for 5 min at room temperature and applied to a $1 \mathrm{~mL}$ Sephacryl S-1000 column at $23^{\circ} \mathrm{C}$ and eluted with buffer $\mathrm{H}$. Fractions contained about $30 \mu \mathrm{L}$.

\section{Binding by FRET}

RNA-to-membrane FRET (Fluorescence Resonance Energy Transfer) between RNA-bound YOYO and membrane-bound Texas Red PE (molecular probes) was measured by exciting YOYO while monitoring its emission decrease due to FRET (Kohout et al. 2003). RNA $(0.6 \mu \mathrm{M}$ in buffer $\mathrm{H})$ was mixed with the cationic cyanide fluorescence dye YOYO-1 iodide (final concentration 6.6 $\mu \mathrm{M})$. The liposomes were added and RNA-to-membrane FRET was monitored by decrease in YOYO emission; $\lambda_{\mathrm{ex}}=466 \mathrm{~nm}$ and $\lambda_{\mathrm{em}}=511 \mathrm{~nm}$ (Janas and Yarus 2003). FRET is highly distance dependent, and becomes efficient only when the RNA enters the membrane, bringing the fluors together.

\section{Permeability using tritiated Trp}

Tritiated amino acids were added (to $0.18 \mu \mathrm{M}$ ) at $4^{\circ} \mathrm{C}$ to a suspension of DOPC vesicles $(6.3 \mathrm{mM}$ lipid) and RNA $(0.6 \mu \mathrm{M})$ in buffer $\mathrm{H}$ where required. Where amino acid concentration was varied, cold tryptophan was also added. Above $1 \mathrm{mM}$ tryptophan, the increased osmotic strength was compensated by increases in internal $\mathrm{NaCl}$ in the liposome preparation. Unilamellar liposomes were prepared from phosphatidylcholine (DOPC; 1,2-dioleoyl-snglycero-3-phosphocholine; Avanti Polar Lipids) at a final concentration of $20 \mathrm{mg} / \mathrm{ml}$, by using the Avanti MiniExtruder with a pore filter diameter of $200 \mathrm{~nm}$. Aliquots were taken at intervals and free amino acid was removed at $4^{\circ} \mathrm{C}$ by two serial passages through ProbeQuant G-50 Sephadex Micro Columns (Amersham) preequilibrated with cold amino acid $(0.2 \mathrm{mM})$ in buffer H. Typically, eight points over about $28 \mathrm{~h}$ were fit with a least-squares exponential to get the rate constant.

\section{Permeability using FRET}

Tryptophan-to-membrane FRET between tryptophan and membrane bound NBD-PE (Cajal et al. 1997) was measured in buffer $\mathrm{H}$ by exciting tryptophan while monitoring both its emission decrease due to FRET $\left(\lambda_{\mathrm{ex}}=300 \mathrm{~nm}\right.$ and $\left.\lambda_{\mathrm{em}}=351 \mathrm{~nm}\right)$ and the NBD-PE emission increase due to FRET $\left(\lambda_{\text {ex }}=300 \mathrm{~nm}\right.$ and $\lambda_{\mathrm{em}}=531 \mathrm{~nm}$ ). In these measurements, a fluor is selectively placed on the inner surface of $100 \mathrm{~nm}$ phospholipid liposomes by forming vesicles with the dye $\mathrm{N}$-(7-nitrobenz-2-oxa-1,3-diazol-4-yl)1,2-dihexadecanoyl-sn-glycero-3-phosphoethanolamine (NBDPE; molecular probes) in both inner and outer membrane leaflets, then destroying the external fluorophore with an aqueous reductant (McIntyre and Sleight 1991). The resulting asymmetrically labeled liposome must be penetrated by Trp in order for the intrinsically fluorescent Trp molecule to be within range for efficient FRET to dye molecules in the inner membrane leaflet. Accordingly, FRET can be used to measure Trp entry.

\section{Liposome fusion assay}

The following liposomal pools were prepared: DOPC liposomes containing buffer $\mathrm{H}$ (50 mM Hepes at $\mathrm{pH} 7.0,50 \mathrm{mM} \mathrm{NaCl}, 5 \mathrm{mM}$ $\mathrm{MgCl}_{2}, 2 \mathrm{mM} \mathrm{CaCl}_{2}$ ) inside; DPX liposomes containing buffer $\mathrm{H}$ and $90 \mathrm{mM}$ quencher DPX (p-xylene-bis-pyridinium bromide, Sigma) inside; ANTS liposomes containing buffer $\mathrm{H}$ and $25 \mathrm{mM}$ fluor ANTS (8-aminonaphthalene-1,3,5-trisulfonic acid, disodium salt, Sigma) inside; control (ANTS + DPX) liposomes containing both ANTS and DPX. The liposomes were extruded in the presence of appropriate solution, and then the liposomes were separated from untrapped material using two subsequent passages through ProbeQuant G-50 Sephadex Micro Columns. The external buffer was adjusted to match the osmotic pressures. Quenching of ANTS fluorescence was monitored at $25^{\circ} \mathrm{C}$ using excitation and emission at $\lambda_{\mathrm{ex}}=354 \mathrm{~nm}$ and $\lambda_{\mathrm{em}}=514 \mathrm{~nm}$, respectively.

\section{ACKNOWLEDGMENTS}

We thank the members of our lab for comments on a draft and also Dr. Joseph J. Falke (University of Colorado, Biochemistry) for use of his spectrofluorometer. This work was supported by NIH Research Grant GM 30881 and NASA Center NCC2-1052.

The publication costs of this article were defrayed in part by payment of page charges. This article must therefore be hereby marked "advertisement" in accordance with 18 USC section 1734 solely to indicate this fact.

Received June 24, 2004; accepted July 9, 2004.

\section{REFERENCES}

Cajal, Y., Boggs, J.M., and Jain, M.K. 1997. Salt-triggered intermembrane exchange of phospholipids and hemifusion by myelin basic protein. Biochemistry 36: 2566-2576.

Chakrabarti, A.C. 1994. Permeability of membranes to amino acids 
and modified amino acids: Mechanisms involved in translocation. Amino Acids 6: 213-229.

Ciesiolka, J., Illangasekare, M., Majerfeld, I., Nickles, T., Welch, M., Yarus, M., and Zinnen, S. 1996. Affinity selection-amplification from randomized ribooligonucleotide pools. Methods Enzymol. 267: 315-335.

Deamer, D., Dworkin, J.P., Sandford, S.A., Bernstein, M.P., and Allamandola, L.J. 2002. The first cell membrane. Astrobiology 2: 371381.

Ellens, H., Bentz, J., and Szoka, F.C. 1985. $\mathrm{H}^{+}$and $\mathrm{Ca}^{+}$-induced fusion and destabilization of liposomes. Biochemistry 24: 3099.

Hanczyc, M.M., Fujikawa, S.M., and Szostak, J.W. 2003. Experimental models of primitive cellular compartments: Encapsulation, growth, and division. Science 302: 618-622.

Janas, T. and Yarus, M. 2003. Visualization of membrane RNAs. RNA 9: 1353-1361.

Janas, T., Janas, T., Kilian, M., and Przestalski, S. 1988. Activation energy of sulfate ion transport across methylated human erythrocyte membranes. FEBS Lett. 236: 93-94.

Khvorova, A., Kwak, Y.-G., Tamkun, M., Majerfeld, I., and Yarus, M. 1999. RNAs that bind and change the permeability of phospholipid membranes. Proc. Natl. Acad. Sci. 96: 10649-10654.

Knight, R., Birmingham, A., and Yarus, M. 2004. BayesFold: Rational $2^{\circ}$ folds that combine thermodynamic, covariation, and chemical data for aligned RNA sequences. RNA 10: 1323-1336.

Kohout, S.C., Corbalan-Garcia, S., Gomez-Fernandez, J.C., and Falke, J.J. 2003. C2 domain of protein kinase C $\alpha$ : Elucidation of the membrane docking surface by site-directed fluorescence and spin labeling. Biochemistry 42: 1254-1265.

McIntyre, J.C. and Sleight, R.G. 1991. Fluorescence assay for phospholipids membrane asymmetry. Biochemistry 30:11819-
11827.

Njagi, E.N.M., Olembo, N.K., and Pearson, D.J. 1992. Proline transport by tsetse fly Glossina morsitans flight muscle mitochondria. Comp. Biochem. Physiol. B 102: 579-584.

Paula, S., Volkov, A.G., Van Hoek, A.N., Haines, T.H., and Deamer, D.W. 1996. Permeation of protons, potassium ions, and small polar molecules through phospholipid bilayers as a function of membrane thickness. Biophys. J. 70: 339-348.

Raphael, R.M. 2001. Fractional occurrence of defects in membranes and mechanically driven interleaflet phospholipid transport. Phys. Rev. E Stat. Nonlin. Soft Matter Phys. 64: 051913/1-051913/10

Sandre, O., Moreaux, L., and Brochard-Wyart, F. 1999. Dynamics of transient pores in stretched vesicles. Proc. Natl. Acad. Sci. 96: 10591-10596.

Schonfeld, P., Schild, L., and Bohnensack, R. 1996. Expression of the ADP/ATP carrier and expansion of the mitochondrial (ATP + ADP) pool contribute to postnatal maturation of the rat heart. Eur. J. Biochem. 241: 895-900.

Smith, J.R., Laver, D.R., and Coster, H.G.L. 1984. The conductance of lecithin bilayers: The dependence upon temperature. Chem. Phys. Lipids 34: 227-236.

Stein, W.D. 1990. Channels, Carriers, and Pumps: An introduction to membrane transport. Academic Press, San Diego, CA.

Vlassov, A., Khvorova, A., and Yarus, M. 2001. Binding and disruption of phospholipid bilayers by supramolecular RNA complexes. Proc. Natl. Acad. Sci. 98: 7706-7711.

Wiener, W.C. and White, S.H. 1992. Structure of a fluid dioleoylphosphatidylcholine bilayer determined by joint refinement of $\mathrm{x}$-ray and neutron diffraction data. Biophys. J. 61: 433-447.

Yarus, M. 2002. Primordial genetics: Phenotype of the ribocyte. Annu. Rev. Genet. 36: 125-151. 

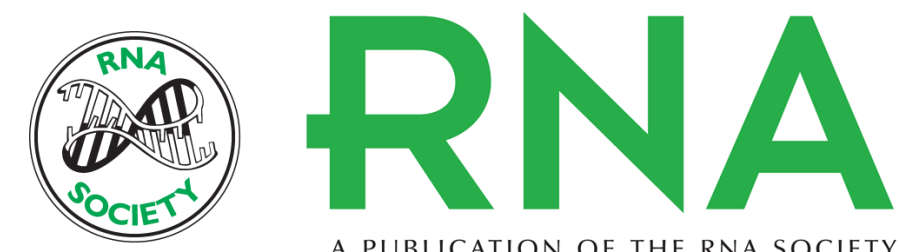

A PUBLICATION OF THE RNA SOCIETY

\section{A membrane transporter for tryptophan composed of RNA}

TERESA JANAS, TADEUSZ JANAS and MICHAEL YARUS

RNA 2004 10: 1541-1549

References This article cites 21 articles, 6 of which can be accessed free at: http://rnajournal.cshlp.org/content/10/10/1541.full.html\#ref-list-1

\section{License}

Email Alerting Receive free email alerts when new articles cite this article - sign up in the box at the top Service right corner of the article or click here. 